\title{
The Institute for the Study of Man in Africa
}

THE Institute's seventh annual Raymond Dart Lecture, entitled 'Language in Africa', was delivered by Professor Desmond T. Cole, Professor of African Languages in the University of the Witwatersrand, on 2 December $197^{\circ}$.

\section{University of Malawi: Lake Chilwa Co-ordinated Research Project}

THE 1966-1970 Research Report of this project, Decline and Recovery of a Lake, is edited by Professor Margaret Kalk, Director of the Project. The work was carried out under the auspices of the University of Malawi, the objectives being to study the biology and changing morphology of the Lake, to assist in a general ecological study of the north-west area of the Chilwa Plain, with a view to biological control of the red locust, and to improved land use, and to measure the radioactivity in certain soils on Chisi Island and its biological effects. A demographic study of the people of the area was made by Professor Swanzie Agnew. The three districts that cover the lake basin are predominantly Yao, Chewa, and Lomwe speaking and there are a large number of foreign-born settlers from Portuguese territory. The I966 Malawi Population Census showed 300,000 lacustrine people settled in villages under their own headmen. This coincided with the lake being in full production but by 1968 all fishing had ceased, following the drying-up of the lake. Periodic fluctuations in lake level make the fishing industry uncertain and the future development of the area may rest primarily on the agricultural potential of the lacustrine plain. The present recovery of the fishing industry and the adaptive responses of the people in the environs have indirectly contributed to the fish-farming proposals in the irrigation schemes for rice and sugar in the Lower Shire Valley and it is expected that the University of Malawi will be called upon to undertake further researches into the changing environments and new patterns of work.

\section{The Chinese Association of African Studies (see also, Africa, xl. 3, 1970, p. 275)}

THE formation of the Chinese Association of African Studies reflects the growing interest in Africa to be found in the Republic of China (Taiwan). The membership at the initial meeting included professors, diplomats, businessmen, returned technicians, students, and others with a general interest in Africa and African affairs. Among the speakers were Mr. Yang Hsi-kuan, the Vice-Minister of Foreign Affairs, and Dr. Tu Twang-hsun, Director of the Program of African Studies at the National Chengchi University. The membership was established and officers nominated at this first meeting. At present three members of the Board of Directors are former Ambassadors to African countries. Publications of an interdisciplinary nature are to be encouraged and projects will be undertaken which will enhance mutual understanding between the republic of China and the countries of Africa. Additional information may be obtained from: The Chinese Association of African Studies, P.O. Box I-9, Mucha, Tapei, Taiwan I6.

\section{The Language Association of Eastern Africa (LAEA)}

LAEA was founded by members of the Language Study Group of Ethiopia, the Kenya Language Association, the Language Association of Tanzania, the Uganda Language Society, and the Zambia Language Group in co-operation with the Survey of Language Use and Language Teaching sponsored by the Ford Foundation (see Africa, xxxix. 3, 1969, pp. 298-9). The Executive Secretary is Mr. Derek Elderkin, University College, Nairobi.

The aim of the association is to further the scientific and professional study of language in all its aspects, to sponsor conferences, workshops, and seminars and to produce a journal 